\title{
Front Matter: Volume 7341
}

, "Front Matter: Volume 7341," Proc. SPIE 7341, Visual Information Processing XVIII, 734101 (1 May 2009); doi: 10.1117/12.831361

SPIE Event: SPIE Defense, Security, and Sensing, 2009, Orlando, Florida, United SPIE. States 


\section{PROCEEDINGS OF SPIE}

\section{Visual Information Processing XVIII}

Zia-Ur Rahman

Stephen E. Reichenbach

Mark A. Neifeld

Editors

14-15 April 2009

Orlando, Florida, United States

Sponsored and Published by

SPIE 
The papers included in this volume were part of the technical conference cited on the cover and title page. Papers were selected and subject to review by the editors and conference program committee. Some conference presentations may not be available for publication. The papers published in these proceedings reflect the work and thoughts of the authors and are published herein as submitted. The publisher is not responsible for the validity of the information or for any outcomes resulting from reliance thereon.

Please use the following format to cite material from this book:

Author(s), "Title of Paper," in Visual Information Processing XVIII, edited by Zia-Ur Rahman, Stephen E. Reichenbach, Mark A. Neifeld, Proceedings of SPIE Vol. 7341 (SPIE, Bellingham, WA, 2009) Article CID Number.

ISSN 0277-786X

ISBN 9780819476074

Published by

SPIE

P.O. Box 10, Bellingham, Washington 98227-0010 USA

Telephone +1 3606763290 (Pacific Time) · Fax +1 3606471445

SPIE.org

Copyright (C) 2009, Society of Photo-Optical Instrumentation Engineers

Copying of material in this book for internal or personal use, or for the internal or personal use of specific clients, beyond the fair use provisions granted by the U.S. Copyright Law is authorized by SPIE subject to payment of copying fees. The Transactional Reporting Service base fee for this volume is $\$ 18.00$ per article (or portion thereof), which should be paid directly to the Copyright Clearance Center (CCC), 222 Rosewood Drive, Danvers, MA 01923. Payment may also be made electronically through CCC Online at copyright.com. Other copying for republication, resale, advertising or promotion, or any form of systematic or multiple reproduction of any material in this book is prohibited except with permission in writing from the publisher. The CCC fee code is 0277-786X/09/ $\$ 18.00$.

Printed in the United States of America.

Publication of record for individual papers is online in the SPIE Digital Library.

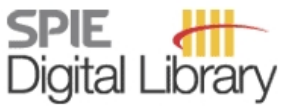

SPIEDigitalLibrary.org

Paper Numbering: Proceedings of SPIE follow an e-First publication model, with papers published first online and then in print and on CD-ROM. Papers are published as they are submitted and meet publication criteria. A unique, consistent, permanent citation identifier (CID) number is assigned to each article at the time of the first publication. Utilization of CIDs allows articles to be fully citable as soon they are published online, and connects the same identifier to all online, print, and electronic versions of the publication. SPIE uses a six-digit CID article numbering system in which:

- The first four digits correspond to the SPIE volume number.

- The last two digits indicate publication order within the volume using a Base 36 numbering system employing both numerals and letters. These two-number sets start with 00, 01, 02, 03, 04, $05,06,07,08,09,0 A, 0 B \ldots 0 Z$, followed by 10-1Z, 20-2Z, etc.

The CID number appears on each page of the manuscript. The complete citation is used on the first page, and an abbreviated version on subsequent pages. Numbers in the index correspond to the last two digits of the six-digit CID number. 


\section{Contents}

vii Conference Committee

\section{SESSION 1 HARDWARE AND VIDEO APPLICATIONS}

734102 An embedded processor for real-time atmoshperic compensation [7341-01] M. R. Bodnar, P. F. Curt, F. E. Ortiz, EM Photonics (United States); C. J. Carrano, Lawrence Livermore National Lab. (United States); E. J. Kelmelis, EM Photonics (United States)

734105 Appearance based key-shot selection for a hand held camera [7341-04]

B. Alefs, J. Dijk, TNO Defense, Security and Safety (Netherlands)

734106 Study of video distortion for real-time video transmission over wireless channels [7341-05]

Z. Chen, D. Wu, Univ. of Florida (United States)

\section{SESSION 2 APPLICATIONS OF IMAGE PROCESSING}

734107 Water quality mapping using Landsat TM imagery [7341-06]

H. S. Lim, M. Z. Mat Jafri, K. Abdullah, A. N. Alias, C. J. Wong, M. R. Mustapha-Rosli, N. Mohd Saleh, Univ. Sains Malaysia (Malaysia)

734108 Visualization and analysis of large three-dimensional hyperspectral images [7341-07] S. E. Reichenbach, X. Tian, R. Lindquist, Univ. of Nebraska, Lincoln (United States); Q. Tao, GC Image, LLC (United States); A. Henderson, J. C. Vickerman, Univ. of Manchester (United Kingdom)

734109 Three-dimensional tracking for efficient fire fighting in complex situations [7341-40] M. Akhloufi, Ctr. de Robotique et de Vision Industrielles (Canada); L. Rossi, CNRS, Univ. of Corsica (France)

7341 OA A new feature front based stereo correspondence technique [7341-08] B. Murali, Univ. of Southern Mississippi (United States) and Essential Knowledge Systems, LLC (United States)

7341 OB Adaptive pattern-based image compression for ultra-low bandwidth weapon seeker image communication [7341-09]

H. Wei, S. Zabuawala, K. M. Varadarajan, J. Yadegar, J. Yadegar, UtopiaCompression Corp. (United States); D. Gray, USAF AFRL/RWGI (United States); J. McCalmont, AFRL/RYJT (United States); J. Utt, Defense Engineering Corp. (United States)

7341 OC Multi-objective evolutionary algorithm based filters for image enhancement [7341-11] L. McLauchlan, Texas A\&M Univ., Kingsville (United States); M. Mehrübeoğlu, Texas A\&M Univ, Corpus Christi (United States) 
7341 OD Bio-inspired color image enhancement model [7341-12]

Y. Zheng, Alcorn State Univ. (United States)

\section{SESSION 4 IMAGE RESOLUTION, REGISTRATION, AND FUSION}

7341 OF Steerable optical flow based image registration: application to aligning human torso images [7341-15]

A. Elsafi, R. Zewail, N. Durdle, Univ. of Alberta (Canada)

$73410 G \quad$ Image registration using conformal log polar mapping [7341-16]

B. K. Vadapally, Z. Rahman, Old Dominion Univ. (United States)

$7341 \mathrm{OH} \quad$ Resolution enhancement of video sequences with real number magnification factor [7341-17]

D. Douglas, Raytheon Space and Airborne Systems (United States); J. Pan, Raytheon Missile Systems (United States)

$73410 \mathrm{Ol}$ Assessment of super-resolution for face recognition from very-low resolution images in sensor networks [7341-18]

J. R. Roeder, S. D. Cabrera, Univ. of Texas at El Paso (United States)

\section{SESSION $5 \quad$ FACE AND EXPRESSION RECOGNITION AND TRACKING}

7341 0J Multispectral face recognition using non linear dimensionality reduction [7341-19] M. A. Akhloufi, A. Bendada, Laval Univ. (Canada); J.-C. Batsale, Ecole Nationale d'Arts et Metiers (France)

$7341 \mathrm{OL} \quad$ An automatic eye detection and tracking technique for stereo video sequences [7341-22] A. Paduru, D. Charalampidis, B. Fouts, Univ. of New Orleans (United States); K. Jovanovich, Omni Technologies, Inc. (United States)

$7341 \mathrm{OM} \quad$ Multi-user vision interface based on range imaging [7341-23]

T. K. Kohoutek, ETH Zurich (Switzerland)

\section{SESSION 6 FEATURE DETECTION, CHANGE DETECTION, AND TRACKING}

$73410 N \quad$ A structural framework for anomalous change detection and characterization [7341-24] L. Prasad, J. Theiler, Los Alamos National Lab. (United States)

734100 A framework for activity detection in wide-area motion imagery [7341-25] R. Porter, C. Ruggiero, J. D. Morrison, Los Alamos National Lab. (United States)

7341 OP Automation of the CCTV-mediated detection of individuals illegally carrying firearms: combining psychological and technological approaches [7341-26]

I. T. Darker, Loughborough Univ. (United Kingdom); P. Kuo, Kingston Univ. (United Kingdom); M. Y. Yang, Univ. of Central Lancaster (United Kingdom); A. Blechko, Loughborough Univ. (United Kingdom); C. Grecos, Univ. of Central Lancashire (United Kingdom); D. Makris, J.-C. Nebel, Kingston Univ. (United Kingdom); A. G. Gale, Loughborough Univ. (United Kingdom) 
$73410 Q$ Detection of facilities in satellite imagery using semi-supervized image classification and auxiliary contextual observables [7341-27]

N. R. Harvey, C. Ruggiero, N. H. Pawley, B. MacDonald, A. Oyer, L. Balick, S. P. Brumby, Los Alamos National Lab. (United States)

7341 OR Summarization and visualization of target trajectories from massive video archives [7341-28] Z. Yue, P. L. Narasimha, P. Topiwala, FastVDO LLC (United States)

7341 OS A change detection approach to moving object detection in low fame-rate video [7341-29] R. Porter, N. Harvey, J. Theiler, Los Alamos National Lab. (United States)

7341 OT Robust tracking of people in crowds with covariance descriptors [7341-30]

J. Metzler, D. Willersinn, Fraunhofer Institute for Information and Data Processing (Germany)

POSTER SESSION

7341 OU Visualizing multidimensional climate model data [7341-31]

J. S. DaPonte, P. Munhutu, Southern Connecticut State Univ. (United States)

734110 Using webcam for indoor air quality monitoring [7341-39]

C. J. Wong, C. K. Teo, M. Z. MatJafri, K. Abdullah, H. S. Lim, Univ. Sains Malaysia (Malaysia)

734111 Fast and robust wavelet-based dynamic range compression and contrast enhancement model with color restoration [7341-44]

N. Unaldi, Turkish Air Force Academy (Turkey) and Old Dominion Univ. (United States);

V. K. Asari, Z. Rahman, Old Dominion Univ. (United States)

Author Index 
Downloaded From: https://www.spiedigitallibrary.org/conference-proceedings-of-spie on 26 Apr 2023

Terms of Use: https://www.spiedigitallibrary.org/terms-of-use 


\title{
Conference Committee
}

\author{
Symposium Chair \\ Ray O. Johnson, Lockheed Martin Corporation (United States) \\ Symposium Cochair
}

Michael T. Eismann, Air Force Research Laboratory (United States)

Conference Chairs

Zia-Ur Rahman, Old Dominion University (United States)

Stephen E. Reichenbach, University of Nebraska, Lincoln (United States)

Mark A. Neifeld, The University of Arizona (United States)

Program Committee

Gary W. Euliss, The MITRE Corporation (United States)

Richard D. Juday, NASA Johnson Space Center (United States)

Ram M. Narayanan, The Pennsylvania State University (United States)

John M. Pellegrino, Army Research Laboratory (United States)

Robert A. Schowengerdt, The University of Arizona (United States)

Joseph van der Gracht, HoloSpex, Inc. (United States)

\section{Session Chairs}

1 Hardware and Video Applications

Mark A. Neifeld, The University of Arizona (United States)

2 Applications of Image Processing

Ram M. Narayanan, The Pennsylvania State University (United States)

3 Image Enhancement

Stephen E. Reichenbach, University of Nebraska, Lincoln (United States)

4 Image Resolution, Registration, and Fusion

Stephen E. Reichenbach, University of Nebraska, Lincoln (United States)

$5 \quad$ Face and Expression Recognition and Tracking

Zia-Ur Rahman, Old Dominion University (United States)

6 Feature Detection, Change Detection, and Tracking

Zia-Ur Rahman, Old Dominion University (United States) 
Downloaded From: https://www.spiedigitallibrary.org/conference-proceedings-of-spie on 26 Apr 2023

Terms of Use: https://www.spiedigitallibrary.org/terms-of-use 